\title{
A HIGH-EFFICIENCY AUTOMATIC DE-BUBBLING SYSTEM FOR LIQUID SILICONE RUBBER
}

\author{
VISOKOZMOGLJIV SISTEM ZA ODPRAVLJANJE MEHURČKOV V \\ TEKOČI SILIKONSKI GUMI
}

\author{
Chil-Chyuan Kuo, Chuan-Ming Huang \\ Ming Chi University of Technology, Department of Mechanical Engineering, No. 84, Gungjuan Road, Taishan Dist. New, \\ Taipei City 24301, Taiwan \\ jacksonk@mail.mcut.edu.tw
}

Prejem rokopisa - received: 2014-06-13; sprejem za objavo - accepted for publication: 2016-10-27

doi:10.17222/mit.2014.089

\begin{abstract}
The silicone-rubber mold is regarded as an important method for reducing the cost and time to market a new product by shortening the development phase. A commercial, automatic, vacuum machine is widely used to degas in the manufacturing of a silicone-rubber mold, but the hardware is costly. A low-cost, high-efficiency degassing system was designed and implemented from a regular vacuum machine. The control style was based on a human-machine interface. It was found that the whole degassing-process sequences consist of the explosive phase, the balanced phase and the convergence phase. The time saving in the degassing process can be at least $42 \%$. Six predicted equations for both the balanced phase and the convergence phase are investigated and the maximum relative error of these equations can be controlled to within $6.34 \%$. The advantages of the developed de-bubbling system include saving labor, reducing the human error of the operator and a higher degassing efficiency.

Keywords: air bubbles, de-bubbling, silicone rubber mold, rapid tooling
\end{abstract}

Forma iz silikonske gume je pomembna pri zmanjševanju stroškov in skrajšanju časa razvojne faze pri uvajanja novega izdelka na trg. Pri izdelavi forme iz silikonske gume se za razplinjevanje uporabljajo drage komercialne vakuumske avtomatske naprave. Iz običajne vakuumske naprave je bil izdelan poceni in učinkovit razplinjevalni sistem. Kontrola stroja temelji na povezavi človek-naprava. Ugotovljeno je, da razplinjevanje sestoji iz eksplozivne faze, faze uravnoteženja in iz faze konvergence, Postopek razplinjevanja omogoča $42 \%$ prihranek časa. Preiskanih je bilo šest predvidenih enačb pri obeh uravnoteženih fazah in pri konvergenčni fazi in maksimalna napaka znaša 6,34 \%. Prednosti razvitega sistema razplinjevanja so: prihranek dela, zmanjšanje človeških napak operaterja in večja učinkovitost razplinjevanja.

Ključne besede: zračni mehurčki, odprava mehurčkov, forma iz silikonske gume, hitra izdelava orodij

\section{INTRODUCTION}

To reduce the time and the cost of product development, rapid prototyping (RP) was developed. ${ }^{1}$ This offers the potential to completely revolutionize the process of manufacture. However, the features of the prototype do not usually meet the needs of the end product with the required material. Rapid tooling (RT) technologies are then developed because it is the technology that uses RP technologies and applies them to the manufacturing of mold inserts. ${ }^{2}$ Since the importance of RT goes far beyond component performance testing, RT is regarded as an important method of reducing the costs and the time to market in a new-product development process. Several RT technologies are commonly available in industry now. RT is divided into direct tooling and indirect tooling. ${ }^{3}$ Direct tooling means fabricating mold inserts directly from an RP machine, such as selective laser sintering. ${ }^{4,5}$ Indirect tooling means fabricating the mold insert by a master pattern fabricated using various RP technologies. Soft tooling is used for low-volume production. The materials used for soft tooling have low hardness levels, such as silicone-rubber ${ }^{6}$ and epoxy-resin composites. ${ }^{7}$ Conversely, hard tooling is associated with higher volumes of production. Materials used for hard tooling often have high hardness levels. Soft tooling is easier to work with than tooling steels because these tools are created from materials such as epoxy-based composites with aluminum particles, silicone rubber or low-melting-point alloys. It is well known that RT is capable of replacing conventional steel tooling, saving costs and time in the manufacturing process. ${ }^{8}$ Indirect soft tooling is used more frequently in the development of new products than direct tooling, because it is fast, simple and cost-effective. It is a well-known fact that a silicone rubber mold is employed frequently because it has flexible and elastic characteristics, so that parts with sophisticated geometries can be fabricated. ${ }^{9}$ A siliconerubber mold can be used for producing low-meltingpoint metal parts, wax patterns and plastic parts. Air bubbles in the silicone-rubber mold are one of the most common types of defects, especially in the vicinity of the master pattern. A silicone-rubber mold with air bubbles appearing in the vicinity of the master pattern will change the appearance and dimensional accuracy of the part duplicated from this silicone-rubber mold using vacuum casting. Conventionally, de-bubbling the air bubbles with a purely manual operation mode depends 
significantly on the experiences of the operator. The drawbacks of this method include human error and noise pollution derived from the vacuum pump. A commercially available automatic vacuum machine was widely employed to degas in the manufacturing of silicone-rubber molds, but the hardware is costly. ${ }^{10}$ In addition, the programmable logic controller mode lacks the flexibility to modify the program. Hence, developing a low-cost and easy-to-operate automated de-bubbling system is a major concern. To meet this requirement, the objective of this work is to develop a low-cost and high-efficiency automatic de-bubbling system with a human-machine interface (HMI). ${ }^{11}$ Three vessels were used for filling the liquid silicone rubber for de-bubbling. The de-bubbling process sequences were investigated in detail. The effect of the pressure-relief process in the explosive phase on the de-bubbling efficiency for manual and automatic modes was also analyzed. Trend equations for predicting the balance phase duration and convergence phase duration for three vessels were investigated. The performance of the automatic de-bubbling system developed was evaluated. Comparisons of the de-bubbling efficiencies for automatic and manual modes were compared.

\section{EXPERIMENTAL PART}

Figure 1 shows a low-cost, automated de-bubbling system with an HMI. This system consists of a photoelectric sensor (EX-11EB; SUNX, Inc.), a programmable logic controller (PLC) (FX 2N-32MR, Mitsubishi), an HMI (GP37W2-BG41-24V; Pro-face, Inc.), an electromagnetic valve (SUG 15-24VDC; Chelic, Inc.) and an

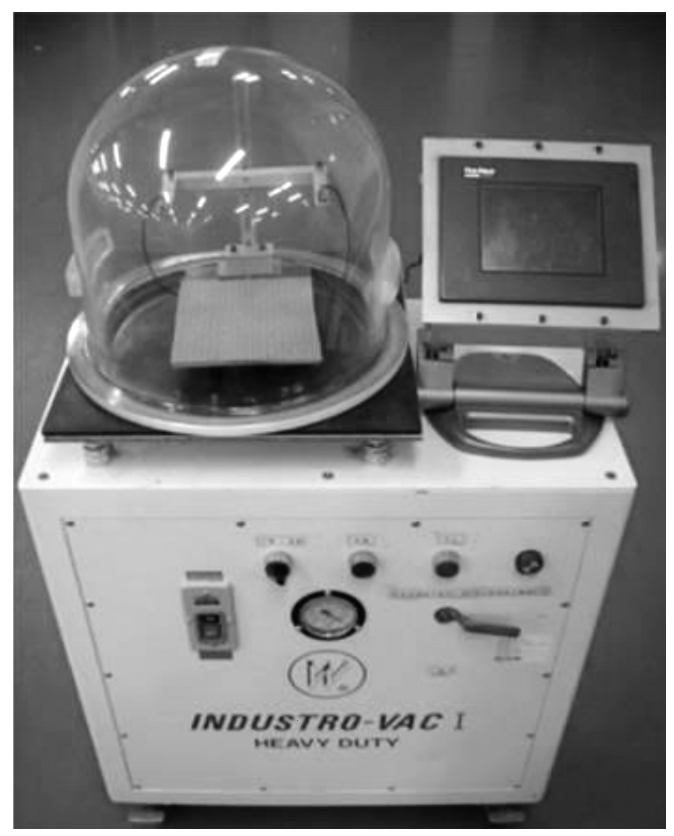

Figure 1: A low-cost, automated, de-bubbling system with an HMI Slika 1: Stroškovno ugoden in avtomatiziran sistem za odpravo mehurčkov s HMI electronic buzzer (TS2BCL; Tend, Inc.). A photoelectric sensor (response time $0.5 \mathrm{~ms}$ ) was used for detecting the air bubbles during the de-bubbling process. A PLC was used as a key component of the electric control module. An HMI was used for operating the automatic debubbling system. The HMI consists of all the aspects of the interaction and communication between the operators and machines by using a graphical HMI unit. The electromagnetic valve (on-off reaction time $<15 \mathrm{~ms}$ ) was used to break the vacuum automatically. An electronic buzzer was used to alert the operator when the debubbling process is completed. Considering the practical requirements for the different operators, the de-bubbling method of this system includes an automation mode and a manual control mode. This system can be equipped with manual and automatic modes. Three different volumes $(250 \mathrm{~mL}, 500 \mathrm{~mL}$ and $1000 \mathrm{~mL})$ of vessels were used for filling the liquid silicone rubber in this study. The silicone rubber (KE-1310ST; ShinEtsu, Inc.) in the liquid state was mixed with a hardener (CAT-1310S; ShinEtsu, Inc). Generally, the curing agent and silicone

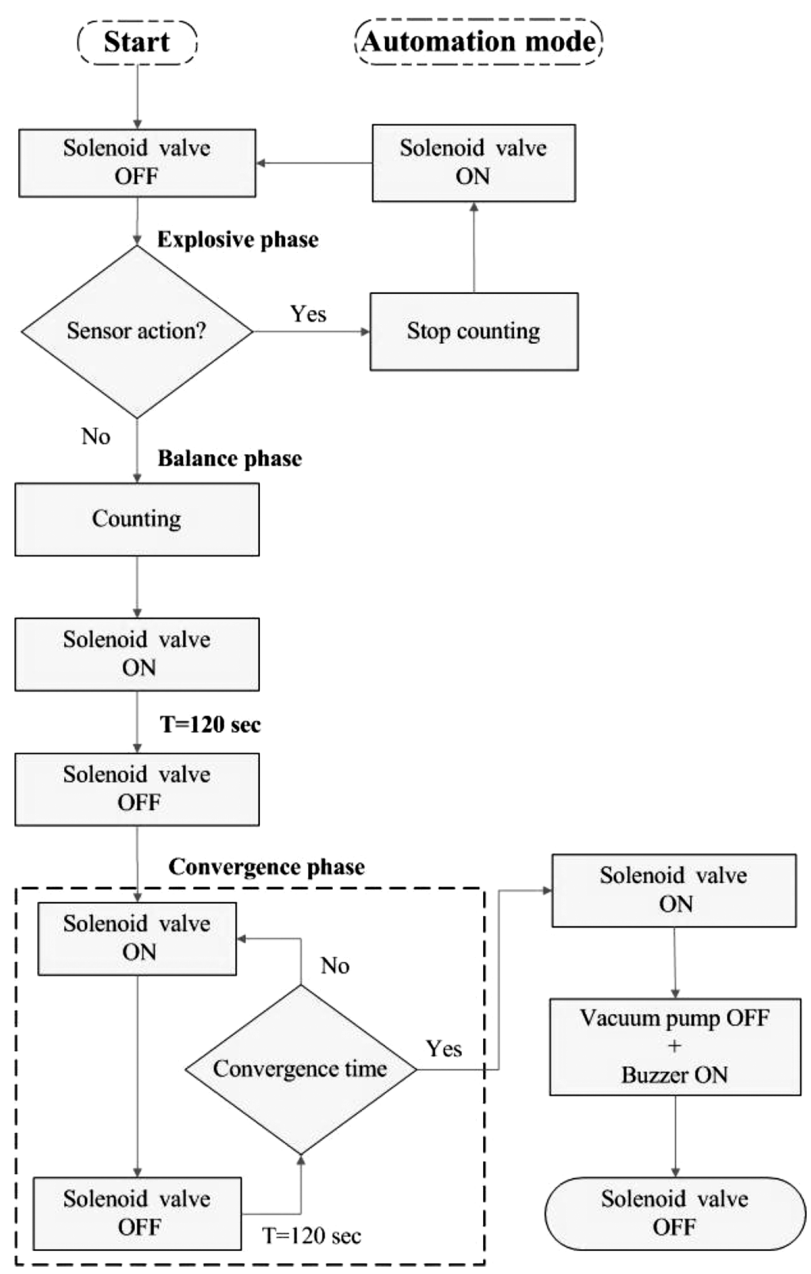

Figure 2: Brief flowchart of the automatic vacuum degassing process using an HMI

Slika 2: Shema poteka postopka avtomatskega vakuumskega razplinjevanja s pomočjo HMI 


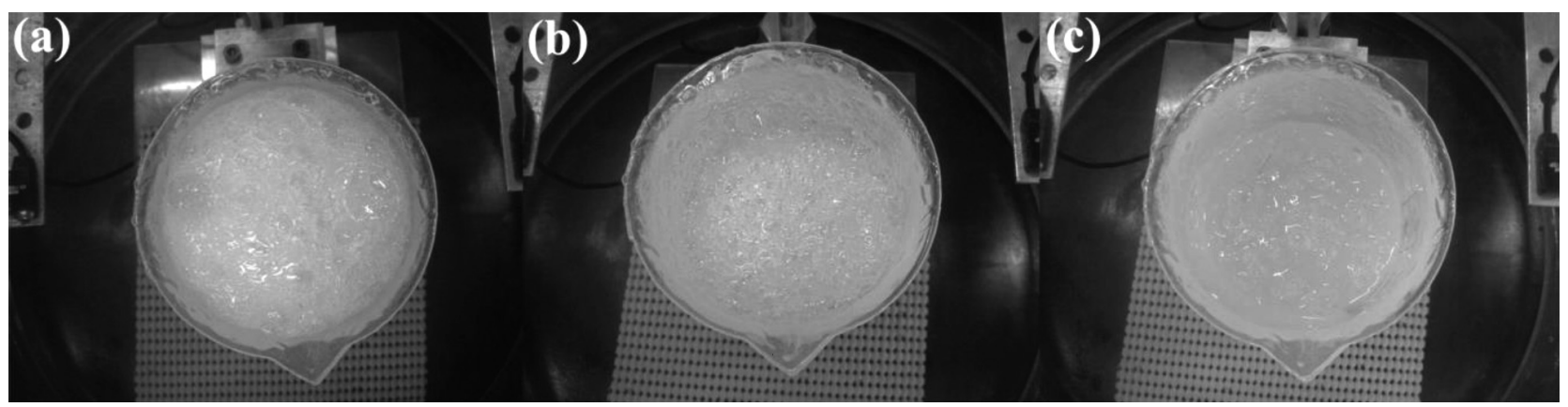

Figure 3: Three phases of the de-bubbling process: a) explosive phase, b) balance phase and c) convergence phase Slika 3: Tri faze postopka razplinjevanja: a) eksplozivna faza, b) ravnotežna faza in c) konvergenčna faza

rubber in a weight ratio of 10:1 were mixed thoroughly with a stirrer. After the de-bubbling process, the pressure inside the vacuum machine was changed by breaking the vacuum atmosphere. Thus, a silicone-rubber mold can be fabricated with defects caused by the air bubbles derived from the mixing process. To reduce the difference caused by the different operators in the amount of air bubbles, while mixing the liquid silicone rubber, an agitation blade for mixing the liquid silicone rubber was designed and fabricated. To confirm the center of the vessel is aligned with the center of the agitation blade, a positioning fixture was designed and fabricated. Figure 2 shows a brief flowchart of the automatic vacuum degassing process using an HMI. Due to the experimental limitations, the solenoid valve does not work when the break vacuum duration is set less than $0.03 \mathrm{~s}$. Thus, the break vacuum duration was set to be $0.03 \mathrm{~s}$.

\section{RESULTS AND DISCUSSION}

The center of the vessel can be aligned with the center of the agitation blade using the positioning fixture. Figure 3 shows the three phases of the de-bubbling process sequences. In general, the liquid silicone rubber has a large number of air bubbles because of the mixing reaction of the materials. As can be seen from this figure,

(a)

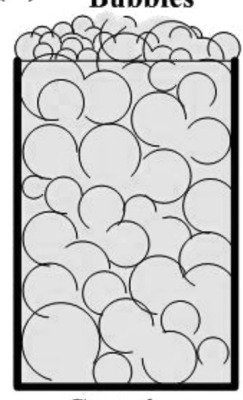

Container (b)

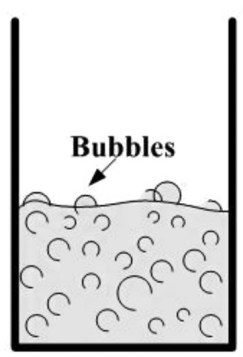

(c)

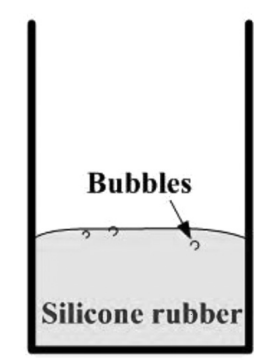

Figure 4: Schematic illustrations of the three phases of the de-bubbling process: a) explosive phase, b) balance phase and c) convergence phase

Slika 4: Shematski prikaz treh faz postopka razplinjevanja: a) eksplozivna faza, b) ravnotežna faza in c) konvergenčna faza the first phase is the explosive phase, where the volume of liquid silicone rubber is drastically increased because the pressure in the vacuum chamber is lower than the atmospheric pressure, as shown in Figure 4a. The second phase is the balance phase, where the air bubbles in the liquid silicone rubber are eliminated gradually, as shown in Figure $\mathbf{4 b}$. The final phase is the convergence phase, where the number and the size of the air bubbles in the liquid silicone rubber are eliminated significantly, as shown in Figure 4c. Schematic illustrations of the three phases of the de-bubbling process are shown in Figure 5. A number of air bubbles less than 15 is defined as the end of balance phase. In addition, no more air bubbles inside the liquid silicone rubber is defined as the end of convergence. A stopping vacuum of 120 s between convergence phase and convergence phase is required for reducing the convergence phase's duration. This is because air bubbles inside the liquid silicone rubber can reach the top of the liquid silicone rubber during $120 \mathrm{~s}$. The air bubbles can be eliminated completely by an automatic de-bubbling system with an HMI based on the criteria discussed above.

Table 1: Time saving of the explosive phase for different volumes of silicone rubber

Table 1: Prihranek časa pri eksplozivni fazi, pri različnih prostorninah silikonske gume

\begin{tabular}{|c|c|c|c|c|}
\hline $\begin{array}{l}\text { Volume of } \\
\text { silicone } \\
\text { rubber }(\mathrm{mL})\end{array}$ & $\begin{array}{c}\text { Percentage } \\
\text { of volume } \\
(\%)\end{array}$ & Mode & $\begin{array}{l}\text { Explosive } \\
\text { phase du- } \\
\text { ration (s) }\end{array}$ & $\begin{array}{l}\text { Time } \\
\text { saving } \\
(\%)\end{array}$ \\
\hline \multirow{2}{*}{350} & \multirow{2}{*}{70} & Manual & 5335 & \multirow{2}{*}{61.46} \\
\hline & & Automatic & 2056 & \\
\hline \multirow{2}{*}{300} & \multirow{2}{*}{60} & Manual & 3952 & \multirow{2}{*}{81.12} \\
\hline & & Automatic & 746 & \\
\hline \multirow{2}{*}{250} & \multirow{2}{*}{50} & Manual & 2883 & \multirow{2}{*}{82.59} \\
\hline & & Automatic & 502 & \\
\hline \multirow{2}{*}{200} & \multirow{2}{*}{40} & Manual & 706 & \multirow{2}{*}{70.00} \\
\hline & & Automatic & 233 & \\
\hline \multirow{2}{*}{150} & \multirow{2}{*}{30} & Manual & 283 & \multirow{2}{*}{61.48} \\
\hline & & Automatic & 109 & \\
\hline \multirow{2}{*}{100} & \multirow{2}{*}{20} & Manual & 0 & \multirow{2}{*}{0} \\
\hline & & Automatic & 0 & \\
\hline
\end{tabular}

Table 1 shows the time saving of the explosive phase for different volumes of silicone rubber. As can be seen, 


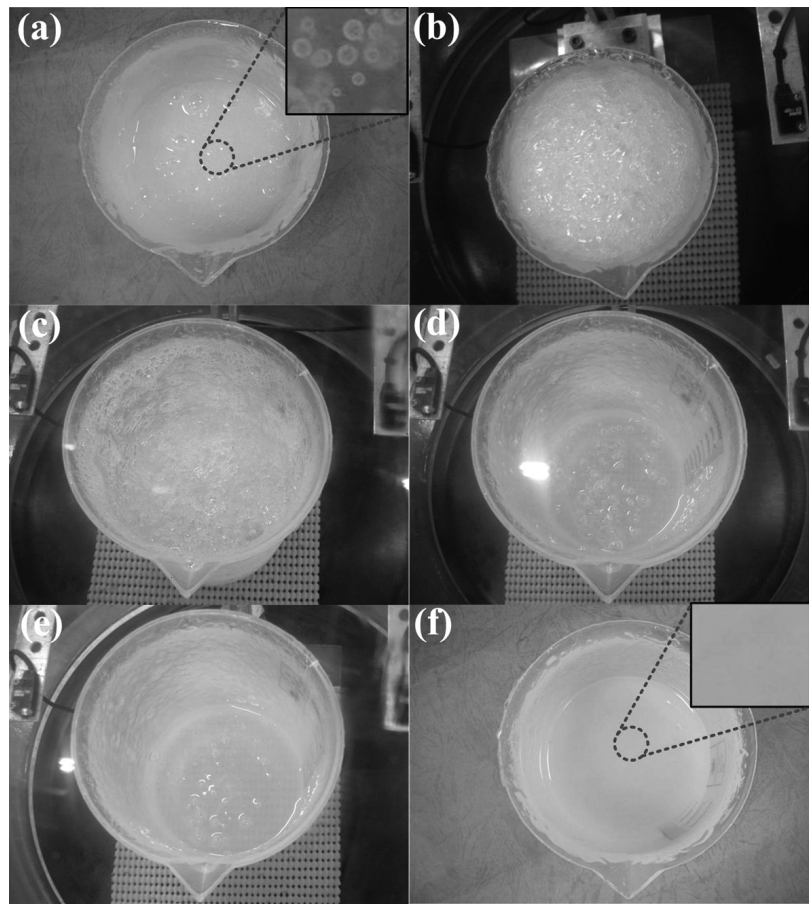

Figure 5: Sequential procedures of the automatic operation mode: a) liquid silicone rubber before de-bubbling process, b) explosive phase, c) balance phase, d) pause $120 \mathrm{~s}$, e) convergence phase and f) de-bubbling process was completed

Slika 5: Sekvenčni postopki pri avtomatskem načinu dela: a) tekoča silikonska guma pred razplinjevanjem, b) eksplozivna faza, c) ravnotežna faza, d) pavza 120 s, e) konvergenčna faza in f) zaključen postopek razplinjevanja

the maximum time saving of the explosive phase is about $81.12 \%$. The time savings of the explosive phase increase with the increasing percentage of volume, ranging from $30 \%$ to $60 \%$. The time saving of the explosive phase decreases when the percentage of volume exceeds $60 \%$. These results show that the vessel with a percentage of volume of $60 \%$ of silicone rubber is the optimum value.

Figure 5 shows the sequential procedures of the automatic de-bubbling process. Figure 6 shows the sequential procedures of the de-bubbling process with manual operation. It is obvious that the results for the two operation modes are the same, showing no air bubbles inside the liquid silicone rubber. This result shows that the air bubbles inside the liquid silicone rubber can be eliminated completely with the automatic operation mode. This means the system can be used for the production of a high-quality, bubble-free, siliconerubber mold. ${ }^{12}$

Precise determination the balance phase's duration and the convergence duration is an absolute requirement for a high-efficiency, automatic, de-bubbling process. Figure 7 shows the trend equations for the balance duration and convergence duration for vessel volumes of $250 \mathrm{~mL}, 500 \mathrm{~mL}$ and $1000 \mathrm{~mL}$. For a vessel volume of $250 \mathrm{~mL}$, the balance phase's duration $(y)$ can be predicted from the trend equation of $y=3.316 x-30.8$ by

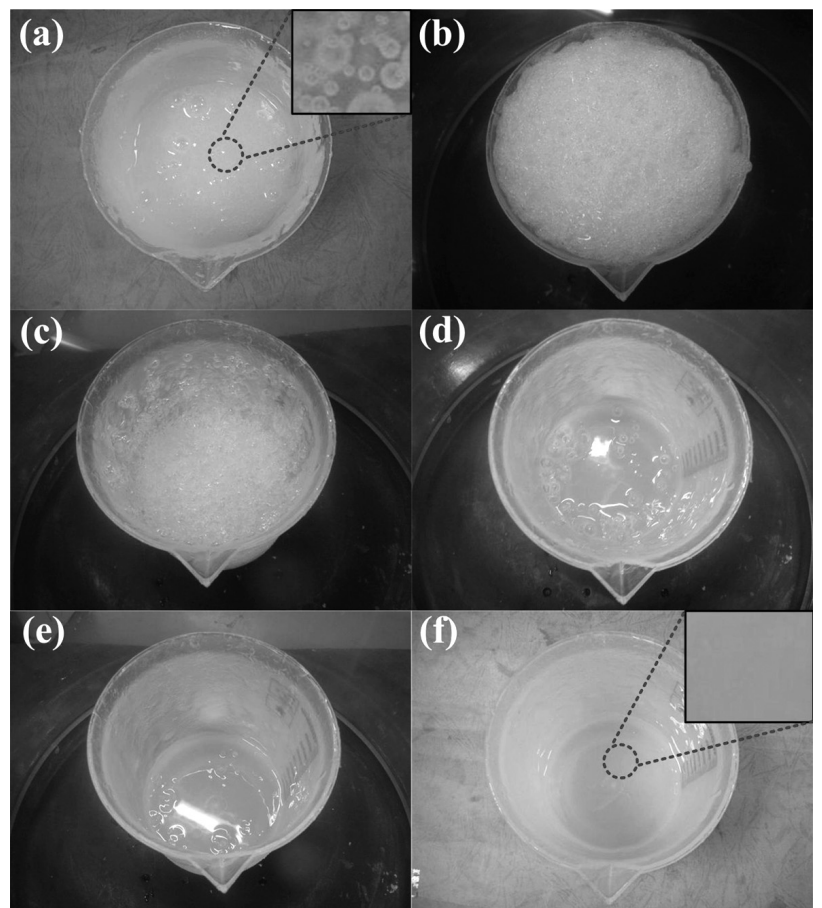

Figure 6: Sequential procedures of the de-bubbling process with the manual de-bubbling mode: a) liquid silicone rubber before de-bubbling process, b) explosive phase, c) balance phase, d) pause $120 \mathrm{~s}$, e) convergence phase and f) de-bubbling process was completed

Slika 6: Sekvenčni postopki postopka razplinjevanja pri ročnem vodenju razplinjevanja: a) tekoča silikonska guma pred razplinjevanjem, b) eksplozivna faza, c) ravnotežna faza, d) pavza $120 \mathrm{~s}$, e) konvergenčna faza in f) zaključen postopek razplinjevanja

the volume of silicone rubber $(x)$. Note that the $R^{2}$ represents the correlation coefficient. Generally, a higher $R^{2}$ value (maximum value $=1$ ) means a better accuracy of the trend equation. ${ }^{16}$ Six predicted equations for both the balanced phase and the convergence phase are investigated, and the maximum relative error of these equations can be controlled within $6.34 \%$. This means that both the balanced phase duration and the convergence phase duration can be calculated from these equations.

To evaluate the performance of the automatic degassing system developed, each test was carried out three times with the mean and the deviation determined. Table 2 shows the time saving of the total degassing time for three different volumes of silicone rubber. Figure 8 shows the total degassing time as a function of silicone rubber for the manual and automatic operation modes. As can be seen, a reduction in the degassing time of at least $42 \%$ can be observed using the automatic degassing system with a human-machine interface. It is obvious that there is an increase in time saving of degassing with an increase in the volume of silicone rubber. Three phases are important for the degassing process, but the explosive phase is the most critical one. This is because the pressure-relief process in the automatic operation mode is significantly different from that in the manual operation mode, as shown in Figure 9. The recovery 

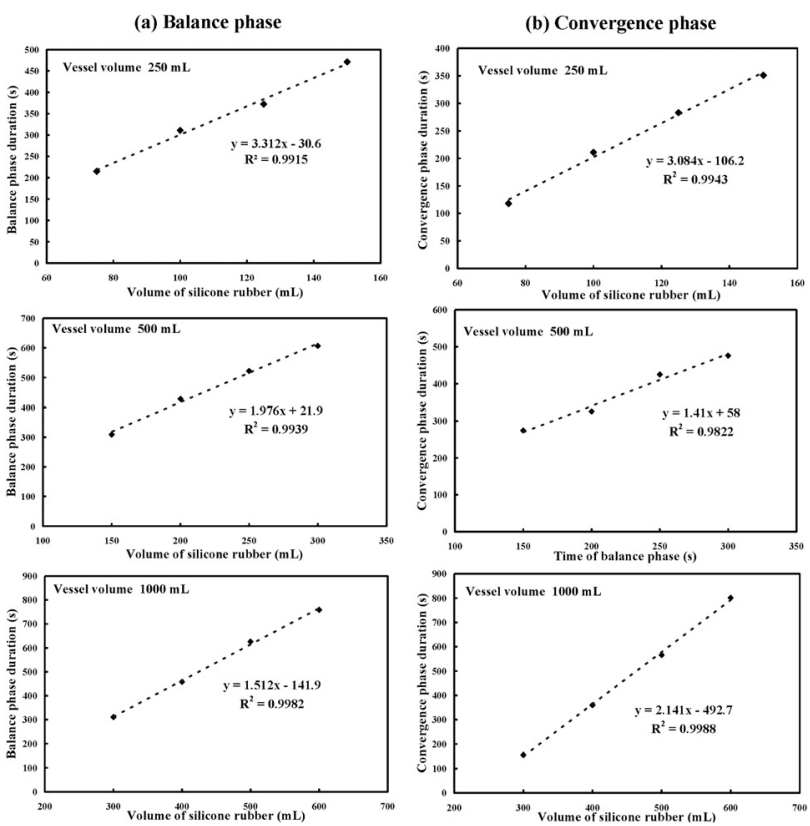

Figure 7: Trend equations of: a) balance phase duration and b) convergence phase duration for vessel volumes of $250 \mathrm{~mL}, 500 \mathrm{~mL}$ and $1000 \mathrm{~mL}$

Slika 7: Trend enačb za: a) trajanje ravnotežne faze in b) trajanje konvergenčne faze pri prostornini posode $250 \mathrm{~mL}, 500 \mathrm{~mL}$ in $1000 \mathrm{~mL}$

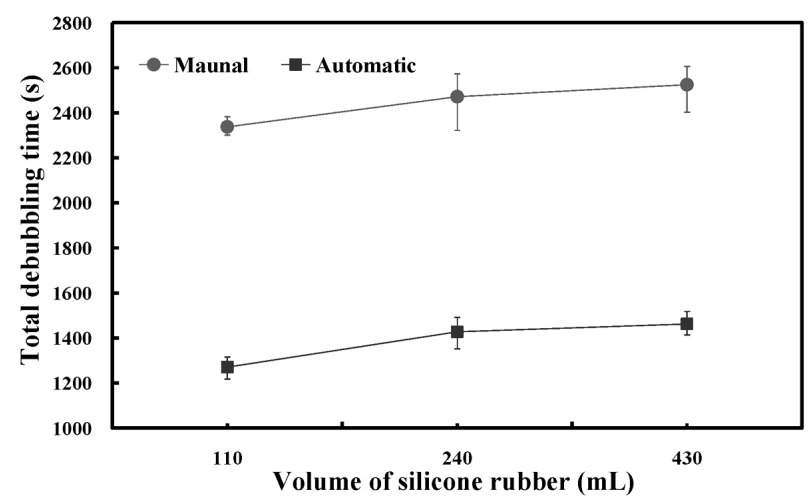

Figure 8: Total degassing time as a function of silicone-rubber volume for manual and automatic operation modes

Slika 8: Celotni čas razplinjevanja (v odvisnosti od volumna) silikonske gume pri avtomatskem in ročnem načinu upravljanja

time needed for the pressure of the chamber reaching the degassing pressure with the automatic operation mode is

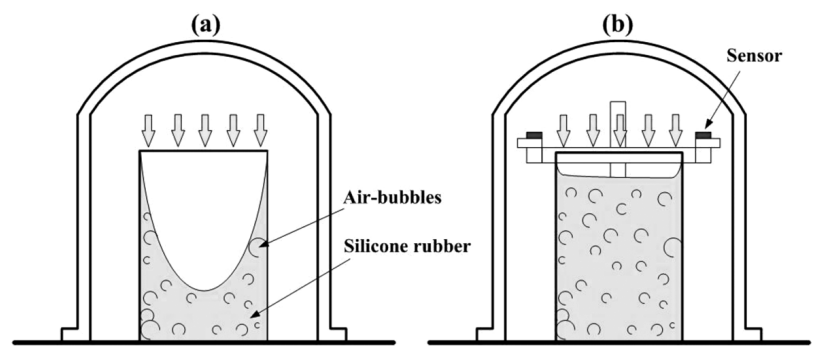

Figure 9: Schematic illustrations of the pressure relief process in the explosive phase: a) manual operation mode and b) automatic operation mode

Slika 9: Shematski prikaz postopka sproščanja tlaka v eksplozivni fazi: a) ročni način vodenja in b) avtomatski način vodenja

shorter than that with the manual operation mode. Based on the experimental results, the advantages of this system include saving labor, reducing the human error of the operator and a higher degassing efficiency. This system has broad application prospects in the development of new products using a silicone-rubber mold.

\section{CONCLUSIONS}

A low-cost, high-efficiency degassing system has been designed, implemented and tested in this study. The entire degassing-process sequences consist of the explosive phase, the balance phase and the convergence phase. The automatic degassing method provides three decisive advantages compared with the manual degassing method. The explosive phase has been proved to be a key process for a high-efficiency degassing process. A reduction of the degassing time by at least $42 \%$ can be gained. This system has broad application prospects in the development stage for new products using rapid-tooling technology.

\section{Acknowledgement}

This work was financially supported by the Ministry of Science and Technology of Taiwan under contract nos. NSC 102-2221-E-131-012 and NSC 101-2221E-131-007.

Table 2: Time saving of the total degassing time for three different volumes of silicone rubber

Tabela 2: Prihranek časa od vsega časa razplinjevanja, pri treh različnih prostorninah silikonske gume

\begin{tabular}{|c|c|c|c|c|c|c|c|}
\hline $\begin{array}{l}\text { Volume of silicone } \\
\text { rubber }(\mathrm{mL})\end{array}$ & Mode & \begin{tabular}{|c|} 
Explosive \\
phase duration \\
$(\mathrm{s})$
\end{tabular} & $\begin{array}{c}\text { Balance phase } \\
\text { duration }(\mathrm{s})\end{array}$ & Pause (s) & $\begin{array}{c}\text { Convergence } \\
\text { phase duration }(s)\end{array}$ & Total (s) & $\begin{array}{c}\text { Time saving } \\
(\%)\end{array}$ \\
\hline \multirow{2}{*}{110} & Manual & 1642 & 338 & 120 & 237 & 2337 & \multirow{2}{*}{45.64} \\
\hline & Automatic & 583 & 334 & 120 & 233 & 1270 & \\
\hline \multirow{2}{*}{240} & Manual & 1415 & 509 & 120 & 427 & 2471 & \multirow{2}{*}{42.24} \\
\hline & Automatic & 416 & 496 & 120 & 396 & 1428 & \\
\hline \multirow{2}{*}{430} & Manual & 1409 & 530 & 120 & 465 & 2525 & \multirow{2}{*}{42.07} \\
\hline & Automatic & 406 & 508 & 120 & 428 & 1462 & \\
\hline
\end{tabular}




\section{C.-C. KUO, C.-M. HUANG: A HIGH-EFFICIENCY AUTOMATIC DE-BUBBLING SYSTEM FOR LIQUID SILICONE RUBBER}

\section{REFERENCES}

${ }^{1}$ M. Laub, H. P. Jennissen, Identification of the anthelix motif in the TGF-b superfamily by molecular 3D-Rapid Prototyping, Materialwissenschaft und Werkstofftechnik, 34 (2003) 12, 1113-1119, doi:10.1002/mawe.200300715

${ }^{2}$ A. Iftikhar, M. Khan, K. Alam, S. H. I. Jaffery, L. Ali, Y. Ayaz, A Khan, Turbine blade manufacturing through rapid tooling (RT) process and its quality inspection, Materials and Manufacturing Processes, 28 (2013) 5, 534-538, doi:10.1080/10426914.2012. 746698

${ }^{3}$ D. K. Pal, B. Ravi, Rapid tooling route selection and evaluation for sand and investment casting, Virtual and Physical Prototyping Journal, 2 (2007) 4, 197-207, doi:10.1080/17452750701747088

${ }^{4}$ S. Singh, V. S. Sharma, A. Sachdeva, S. K. Sinha, Optimization and analysis of mechanical properties for selective laser sintered polyamide parts, Materials and Manufacturing Processes, 28 (2013) 2, 163-172, doi:10.1080/10426914.2012.677901

${ }^{5}$ J. Liu, H. Hu, P. Li, C. Shuai, S. Peng, Fabrication and characterization of porous $45 \mathrm{~S} 5$ glass scaffolds via direct selective laser sintering, Materials and Manufacturing Processes, 28 (2013) 6, 610-615, doi:10.1080/10426914.2012.736656

${ }^{6}$ D. Juarez, R. Balart, T. Boronat, M. J. Reig, S. Ferrandiz, Validation of the use of SEBS blends as a substitute for liquid silicone rubber in injection processes, Materials and Manufacturing Processes, 28 (2013) 11, 1215-122, doi:10.1080/10426914.2013.811732

${ }^{7}$ R. Azim, M. T. Islam, Design of a wideband planar antenna on an epoxy-resin-reinforced woven-glass material, Mater. Tehnol., 49 (2015) 2, 193-196, doi:10.17222/mit.2013.169

${ }^{8}$ C. C. Kuo, A cost-effective approach to the rapid fabrication of functional metal prototypes, Mater. Tehnol., 48 (2014) 4, 581-585

${ }^{9}$ C. C. Kuo, C. Y. Lin, Development of bridge tooling for fabricating mold inserts of aspheric optical lens, Materialwissenschaft und Werkstofftechnik, 42 (2011) 11, 1019-1024, doi:10.1002/mawe. 201100819

${ }^{10}$ Y. Tang, W. K. Tan, J. Y. H. Fuh, H. T. Loh, Y. S. Wong, S. C. H. Thian, L. Lu, Micro-mould fabrication for a micro-gear via vacuum casting, Journal of Materials Processing Technology, 192-193 (2007), 334-339, doi:10.1016/j.jmatprotec.2007.04.098

${ }^{11}$ A. Jaklič, F. Vode, R. Robič, F. Perko, B. Strmole, J. Novak, J. Triplat, The implantation of an online mathematical model of slab reheating in a posher-type furnace, Mater. Tehnol., 39 (2005) 6, 215-220

${ }^{12}$ C. C. Kuo, Y. J. Wang, Development of a micro-hot embossing mold with high replication fidelity using surface modification, Materials and Manufacturing Processes, 29 (2014) 9, 1101-1110, doi:10.1080/ 10426914.2014.912312 